\title{
ILMU KOLONIAL DAN ISLAMISASI ALAM MELAYU: ANALISIS KRITIKAL
}

\author{
Rahimin Affandi Abd. Rahim \\ Siti Maimunah Binti Kahal
}

\begin{abstract}
Malaysia as a colonized nation had faced several negative impact imposed by the British. It including in the epistemological aspect which disturb Islam as source of Malay-Muslim's self-esteem. The study analyse the British's colonial work on the issues of Islamizatioin of the peninsula of Malaya.The Malay Muslims were forced passively to accept the colonialization of the British power with positive outlook. In fact, we try to reconstruct a historical misconceptions expressed by colonial scholars. The study finds several false account proposed by colonial works on the Islamization of the Malay world, namely the role of Aceh in inoculating the acts of violence in Malay world and denial of positive role played by Islam in the Malay world.
\end{abstract}

\section{Pengenalan}

Alam Melayu pernah terdedah dan berinteraksi dengan pelbagai bangsa asing. Antaranya bangsa India, Arab, Parsi, Cina dan Eropah. Ia termasuk juga dengan agama besar dunia seperti Hindu, Buddha, Islam dan Kristian. Oleh sebab itu, daripada aspek hubungan dan pendedahan luar, masyarakat Alam Melayu amat dinamik sekali kerana menjadi tempat pertemuan pelbagai budaya dan tamadun besar dunia. Proses ini berlaku dalam bentuk yang adil dan timbal balik. Ia terdorong dengan sifat masyarakat Alam Melayu yang berbentuk terbuka dengan pengaruh luar. Hal ini berbeza kemudiannya dengan kedatangan kuasa penjajah Barat. Kedatangan kuasa Eropah telah mencetuskan suasana tegang kerana pelbagai pendekatan jahat yang diamalkan oleh kuasa Barat ini. Kedatangan dan pembabitan kuasa Eropah ini dapat dibahagikan kepada beberapa peringkat:

\section{Era Sebelum Penjajahan Alam Melayu}

Di zaman ini, masyarakat luar memang banyak yang merantau ke Alam Melayu, termasuklah bangsa Eropah. ${ }^{1}$ Merujuk khusus kepada bangsa British, mereka terlibat secara aktif sebagai pedagang kecil-kecilan yang dikenali sebagai pedagang tempatan di kawasan Alam Melayu. Sejak awal lagi, barang dagangan yang diniagakan adalah barangan yang memudaratkan seperti hamba, candu dan senjata api. Selain itu, mereka terlibat sama mengumpul maklumat tentang kawasan pelabuhan Alam Melayu yang disalurkan kepada kuasa besar di Eropah. Golongan ini banyak melobi dan meyakinkan kuasa di Eropah tentang prospek perdagangan di Alam Melayu bagi menghentikan monopoli barangan berharga seperti rempah yang dikuasai oleh pedagang Islam. Sebagai contohnya, pedagang tempatan ${ }^{2}$ bertanggungjawab mengumpul maklumat tentang negeri Melayu dan mempengaruhi kerajaan British di India untuk campurtangan di Tanah Melayu. Antara maklumat ini adalah Terengganu sebagai pelabuhan core $^{3}$ yang maju - terkenal dengan bahan ekspot emas dan lada hitam. Terengganu telah menjadi rebutan antara pihak British dengan Belanda yang memandang ianya terletak dalam kawasan dagang yang strategik; jalan dagang antara Tanah Melayu dengan China ataupun tempat persinggahan jalan dagang antara kawasan timur dan barat.

Dalam hal ini, Kapten Joseph Jackson menulis: "Terengganu adalah negeri yang kaya dan maju dan mempunyai pelbagai jenis barangan.Orang china mempunyai penempatan yang besar dan menjalankan perdagangan yang giat disini." Pelabuhan Terengganu dan Pahang 
dikatakan bersifat kosmopolitan dengan pelbagai bangsa seperti China, Arab, Parsi dan sebagainya. Urus niaga berjalan dengan baik kerana pemerintahnya Sultan Mansur menyedari kepentingan menjalinkan hubungan dagang dengan kuasa besar (China, India dan Tanah Arab) pada masa itu. Hubungan diplomatik memang wujud antara kerajaan British di India dengan pedagang British yang menjadi orang tengahnya. Berlaku pertukaran barangan dagang antara Terengganu dengan British. Ianya terdiri daripada emas, timah, lada hitam, beras, senjata api dan candu. ${ }^{4}$

\section{Era Penjajahan Kuasa Eropah di Kawasan Alam Melayu}

Kuasa penjajah telah memperkenalkan pendekatan yang sangat buruk seperti tipu muslihat, monopoli dan penindasan dalam mengembangkan kuasa di Alam Melayu. Hal ini jauh berbeza dengan bentuk interaksi yang berlaku di antara pelbagai bangsa di Alam Melayu sebelumnya. Bagi sesetengah sarjana seperti Abdul Rahman Embong dan Syed Muhd Khairudin al-Junied, era ini dianggap sebagai globalisasi gelombang kedua berlaku dengan kedatangan pelbagai kuasa penjajah Barat yang bersifat menindas (contohnya pihak Barat membahagikan dunia kepada dunia dan kawasan tanah jajahan, wujudnya perniagaan hamba, rosaknya demografi penduduk pribumi dengan datangnya bangsa imigran asing dan lahirnya ilmu orientalis yang menyebar idea kelemahan bangsa dijajah yang kekal sehingga kini.

Sejarah telah mencatatkan bagaimana pada peringkat awalnya, kuasa penjajah British di Alam Melayu telah menjalankan dasar yang tidak campurtangan dalam soal agama dan adat resam, tetapi secara realitinya hal yang sebaliknya telah berlaku apabila pihak British turut mencampuri kedua-dua bidang ini. ${ }^{5}$ Lebih penting lagi, pihak British telah cuba menghapuskan potensi dan mekanisme penggerak yang terdapat di dalam ajaran Islam. Di dalam usaha mereka mengkaji tentang cara yang terbaik untuk menghapuskan akar dan asas kekuatan Islam yang selama ini terjalin erat di antara umat Islam di rantau Alam Melayu, dengan khidmat nasihat dari serangkaian sarjana-pentadbir orientalis, yang bertugas mengkaji kekuatan dan kelemahan umat Melayu dan seterusnya dicadangkan cara terbaik untuk menangani persoalan ini.

Dalam konteks Tanah Melayu, pendekatan penghapusan potensi Islam dapat dikesan daripada:

Pertama, memperkenalkan konsep nation state berasaskan semangat asabiyyah sempit kepada sesuatu negeri dan kawasan yang tertentu menggantikan semangat perpaduan ummah Islam. ${ }^{6}$ Dasar ini merupakan usaha untuk memecahbelahkan perpaduan umat Melayu di rantau ini agar ianya tidak menjadi ancaman kepada kuasa penjajah Barat, ${ }^{7}$ seperti mana yang pernah berlaku sebelumnya. Bagi menjelaskan pendekatan ini, kita boleh merujuk kepada dasar penjajah British dan Belanda yang begitu bimbangkan peranan institusi haji ${ }^{8}$ dan pendidikan Islam di Timur Tengah, yang dimaklumi oleh mereka pernah menjadi sebagai penggerak utama kepada jalinan ukhuwah Islam di rantau Alam Melayu.

Kedua, penerapan proses sekularisme di dalam masyarakat Melayu dan memperkenalkan sistem pendidikan Barat. ${ }^{9}$ Jelasnya, kita boleh melihat bahawa sebab utama berlakunya jalinan perpaduan ini adalah kerana faktor Islam dan ilmu pengetahuan. Oleh itu, dalam soal ini, pihak British secara halus cuba menghapuskan institusi pengajian Islam tradisional berasaskan pengetahuan Islam dan tulisan Jawi. ${ }^{10}$ Kedua-duanya telah dijadikan sasaran utama yang ditonjolkan kepada masyarakat Melayu sebagai ketinggalan zaman, tidak mempunyai nilai-nilai komersial dan menyekat semangat intelektual moden. ${ }^{11}$ Sebagai gantinya, penjajah British telah memperkenalkan sistem persekolahan British berteraskan pemberian pengetahuan am yang amat terhad ${ }^{12}$ dan bersifat perkauman untuk ketiga etnik kaum yang terdapat di Tanah Melayu. ${ }^{13}$ Pihak British telah menerapkan di dalam mata pelajaran yang diajarkan bahawa mereka sebagai hero, penyelamat kepada orang Melayu ${ }^{14}$ dan ambassador of civilization ${ }^{15}$ untuk masyarakat di Alam Melayu. 
Dasar penjajah telah meninggalkan kesan epistemologi negatif yang kekal sehingga selepas Malaysia merdeka. Dasar-dasar itu antaranya ialah seandainya kemajuan dan pembangunan ingin dilaksanakan, negara bekas tanah jajahan (negara sedang membangun) perlu menjalankan sistem Barat yang bernuansa fahaman sekular dalam segenap segi kehidupan. ${ }^{16}$ Selain itu, semua sistem yang bertentangan dengan pandangan alam Barat seperti sistem Melayu-Islam akan dianggap sebagai ketinggalan zaman dan hanya mementingkan suatu etnik tertentu semata-mata.

Pihak British juga memperkenalkan kerangka pemikiran sekularisme dalam pemikiran masyarakat Melayu. Ia terdiri daripada:

a. Pengosongan alam tabii dan akal insani daripada unsur ketuhanan - manusia bebas melakukan sesuatu program pembangunan tanpa mempedulikan kuasa Tuhan.

b. Penafian terhadap kekuasaan politik yang berdasarkan sumber agama.

c. Pengenalan sistem penilaian nisbi/relatif terhadap agama; manusia bebas menentukan masa depannya sendiri.

d. Penurunan taraf ilmu agama, berbanding dengan ilmu bukan agama - tumpuan lebih diberi kepada ilmu bukan agama yang kononnya boleh membawa kemajuan.

e. Penakrifan konsep kebenaran yang keliru dan mengikut paradigma sekularisme.

\section{Era Pasca Merdeka}

Di dalam era ini kesan penjajahan epistemologi terus kekal yang menimbulkan pelbagai masalah. Dalam konteks sejarah Alam Melayu, kebanyakan sarjana Barat telah mengaitkan proses pemodenan yang timbul adalah kerana faktor penjajahan kuasa Barat, khususnya pihak British $^{17}$ dan menolak hujah bahawa Islam yang meninggalkan pengaruh yang baik ke atas masyarakat Melayu.

Antara elemen pemodenan yang kononnya telah dibawa masuk ataupun dipaksakan ${ }^{18}$ ke atas masyarakat Melayu oleh kuasa penjajah British adalah mewujudkan kemudahan infrastruktur moden seperti sistem jalanraya, talian telefon, hospital dan sebagainya, ${ }^{19}$ mewujudkan sistem pendidikan vernakular ala British untuk tiga etnik kaum yang berbeza, ${ }^{20}$ menanamkan sikap yang lebih terbuka dan keberanian untuk mengkritik kepincangan yang dilakukan oleh pembesar Melayu ${ }^{21}$ dan memperkenalkan sistem pentadbiran di semua peringkat yang lebih tersusun termasuklah dalam sektor berkaitan dengan Islam. ${ }^{22}$

Di sebalik elemen pemodenan ini, jika diteliti secara mendalam, akan terlihat bahawa kesemua contoh pemodenan ini diperkenalkan adalah untuk tujuan kepentingan politik dan ekonomi kuasa British dan ia tidak dilakukan untuk tujuan kebaikan masyarakat Melayu. ${ }^{23}$ Hal ini telah disokong dengan kenyataan oleh seorang sarjana yang menyatakan;

While the new urban society became richer and was provided with all the material comforts of civilization, the rural Malays remained in poverty. The Malays had a money economy thrust upon them, but they had little means of earning the same money to buy the goods that came with a money economy. While the British were consciously and deliberately creating a modern economic system consonant with world commercial development, the Malays were driven more into the backwoods of economic progress. ${ }^{24}$

Kenyataan ini secara jelas mendedahkan bagaimana semua nikmat pemodenan yang kononnya diusahakan oleh kuasa British ini tidak dapat dinikmati oleh orang Melayu, bahkan untuk jangka masa yang panjang kemudiannya telah menimbulkan masalah perpaduan di Tanah Melayu. $^{25}$

Merujuk kepada Tanah Melayu, dasar penjajah British telah meninggalkan kesan jangka panjang yang merangkumi ${ }^{26}$ masalah perkauman sebagai akibat dasar berat sebelah 
yang dilakukan kepada masyarakat Melayu. Antaranya mereka menjaga secara berlebihan golongan pembesar Melayu yang dipersediakan untuk menjadi alat mereka menguasai masyarakat awam Tanah Melayu. Kesan yang lain adalah seperti masalah kemunduran pendidikan orang Melayu, masalah bias dan stereotaip tentang pelbagai bangsa di Tanah Melayu dan masalah perkauman masyarakat Tanah Melayu yang serius akibat dasar penjajah British.

\section{Kepentingan Ilmu Kolonial dalam Menkonstruk Sejarah Alam Melayu}

Di Eropah pada zaman proses kolonialisme berjalan, projek Enlightmen dan Renaissance (program menghidupkan falsafah positivisme - sekularisme) sedang giat berjalan dan falsafah ini diterima oleh kerajaan Britain dalam kebanyakan dasar negara. ${ }^{27}$ Oleh itu, kuasa penjajah British di peringkat pusat (negeri asal) telah menetapkan beberapa dasar.

Pertama, demi untuk memastikan penjajahan dapat bertahan lama, ia memerlukan ilmu untuk menjayakan program ini. Jadi mereka memerlukan pakar-pakar yang terlatih untuk tujuan mengkaji kekuatan dan kelemahan masyarakat tanah jajahan. Atas sebab itu, Institusi Pengajian Tinggi di Barat (British dan Belanda) telah melatih kader-kader ini tentang sejarah, bahasa, budaya dan ilmu filologi bagi menjalankan misi mendapatkan maklumt tentang masyarakat tanah jajahan. ${ }^{28}$ Misi mengumpulkan maklumat tentang masyarakat tanah jajahan untuk tujuan pentadbiran masyarakat memang telah dikumpulkan dengan banyak sekali, yang dipelopori oleh sejarawan Portugis, ${ }^{29}$ Belanda $^{30}$ dan British. ${ }^{31}$ Secara langsung koleksi ini berteraskan world-view Barat tanpa mempedulikan kepentingan dan kebajikan masyarakat tanah jajahan. Maknanya, mereka mengumpul dan mengolahnya daripada sudut pandangan mereka, yang menyebabkan sebahagian besarnya tidak mewakili kepentingan masyarakat tanah jajahan, walaupun dikatakan kedatangan mereka untuk mentamadunkan masyarakat tanah jajahan. ${ }^{32}$

Kedua, pihak pusat perlu menerimapakai cadangan yang diberikan oleh pakar-pakar orientalis ini. Contoh yang paling jelas dalam soal ini adalah dasar mewajibkan penggunaan bahasa penjajah di sekolah masyarakat tanah jajahan. Hal ini telah dijalankan mengikut cadangan yang dikemukakan oleh sarjana orientalis, di Tanah Melayu dan India serta pihak Belanda di Indonesia. ${ }^{33}$

Ketiga dan terpenting sekali, penjajah Barat dengan bantuan sarjana-pentadbir orientalis di tanah jajahan cuba menakluki ruang geo-politik dan ruang epistemologi masyarakat tanah jajahan menggunakan genre orientalism. Mereka telah menggunakan ilmu kolonial berasaskan kerangka epistemologi rationalism bagi membincangkan tentang agama: budaya, alam sekitar, tanah tanih, struktur masyarakat, bahasa dan sebagainya. Kerangka asas keilmuan kolonial ini sebagai konstruksi ilmu masih lagi digunapakai secara meluas sehinggalah selepas Malaysia mencapai kemerdekaan. Hal ini dijelaskan oleh Shamsul Amri Baharuddin $;^{34}$

Kalau kita singkap kembali sejarah imperialism dan kolonialisme barat kita akan bertemu dengan bukti jelas tentang peri pentingnya ilmu dan analisis sosial untuk pemerintahan. Misalnya, ilmu kolonial atau colonial knowledge, cukup penting untuk sesebuah kuasa imperialis mengasaskan kekuasaannya di kawasan jajahannya. Kalau kekuatan ketenteraannya membolehkan sebarang kuasa penjajah menakluki secara fizikal sesebuah ruang geo-politik, melalui ilmu kolonial pula penjajah tersebut mampu menakluki ruang epistemologi, iaitu ruang sistem pemikiran and intelektual masyarakat peribumi yang dijajah. Bak aur dengan tebing, kedua-dua komponen tersebut, yang terdapat dalam proses penaklukan-penjajahan ini, tersulam satu and sukar untuk dipisahkan. 


\section{Raffles Sebagai Pengasas Ilmu Kolonial di Alam Melayu}

Ketokohan Raffles dalam mengasaskan ilmu kolonial bagi menangani masyarakat Melayu memang diakui ramai. ${ }^{35}$ Walaupun beliau tidak mendapat asas pendidikan tinggi dalam bidang pengajian Melayu dan Islam sepertimana tokoh sarjana-pentadbir orientalis lain, tetapi beliau memang menganut fahaman logico-positivesm ${ }^{36}$ dalam mengkaji masyarakat Melayu. Dalam banyak hal ia mengasaskan kaedah pembinaan metodologi ilmu kolonial. Antara asasasas ini adalah:

Status Melayu dan daerah dunia Melayu dihadkan kepada Tanah Melayu dan beberapa lokasi tertentu. Dalam usaha ini, ia telah berjaya memecahbelahkan masyarakat Melayu di Alam Melayu. Ia memperkenalkan had sempadan seperti mana difahami oleh konsep nation state dalam dunia Barat. Asas yang diletakkan ini kemudiannya diteruskan oleh pentadbir British lain seperti Winstedt, Wilkilson, Swethenam, Linelhan, Hugh Clifford dan ramai lagi.

Raffles menganggap orang Islam sebagai bangsa ganas yang penuh dengan pelbagai elemen negatif seperti mana disentuh oleh sarjana orientalis klasik. Dalam soal ini, ia terlibat dalam usaha misionari Kristian yang menganggap Islam sebagai musuh utama akibat daripada Perang Salib.

Selain itu, Islam tidak memberi apa-apa impak positif kepada masyarakat Melayu. Bahkan pengaruh pra-Islam (Hindu-Buddha dan anamisme) dianggap lebih baik berbanding dengan Islam. Hal ini ditegaskan oleh Raffles berulang kali walaupun beliau memaklumi pencapaian intelektual ulama Islam di abad ke 16-17 dengan penghasilan karya Kitab Jawi. Hal ini terbukti apabila beliau menjalankan polisi mendapatkan sebanyak mungkin manuskrip Islam daripada masyarakat Melayu, dengan melantik Abdullah Munsyi sebagai ejen untuk usaha pengumpulan manuskrip Melayu Islam ini. Boleh dikatakan sebahagian besar daripada koleksi manuskrip Melayu Islam di muzium British adalah hasil usaha beliau. ${ }^{37}$

Raffles juga mengeluarkan pandangan bahawa andainya tradisi Hindu masih berkuasa sudah pasti tamadun Melayu akan menjadi maju. Hal ini terbukti dengan wujudnya monumen Hindu seperti Candi Borobudur yang sangat hebat. Sedangkan Islam tidak mempunyai kesemua monumen ini. Dalam banyak hal, beliau menghargai budaya Hindu yang menekankan kasta kerana ketaatan masyarakat bawahan kepada kasta atasan akan memudahkan kuasa British menguasai politik-ekonomi masyarakat tanah jajahan. Lebih penting lagi, dalam agama Hindu tiada fahaman jihad melawan penjajah yang bakal menjejaskan kuasa penjajah British.

Bangsa Melayu juga dianggap sebagai bangsa mundur, primitif, tidak boleh dipercayai dan tidak memiliki kapasiti kepintaran akal untuk membina tamadun. Mereka perlu dijajah untuk mentamadunkan bangsa Melayu.

Oleh itu, usaha pembinaan ilmu kolonial untuk menguasai masyarakat Melayu perlu didasarkan kepada enam kaedah utama yang menjadi taktik standard yang perlu diikuti oleh pentadbir British yang lain. Lebih teliti lagi, metodologi pembinaan ilmu kolonial ini dibuat melalui beberapa proses:

a. Menguasai bahasa pribumi untuk membolehkan proses komunikasi dan menjalankan program law and order di dalam masyarakat.

b. Menjalankan survey ataupun kajian tinjauan bagi mengumpulkan maklumat mengenai kehidupan sosial, alam sekitar dan segala perkara yang berkait dengan masyarakat pribumi.

c. Mengumpul maklumat statistikal melalui kaedah banci yang kemudiannya dikategorikan mengikut pembahagian yang khusus.

d. Menyimpan pelbagai bahan dan artifak yang dikutip dari survey and banci untuk dipamerkan kepada kalangan yang berminat. 
e. Mengasaskan suatu sistem pengintipan dan perisikan yang dianggap perlu bagi menjamin keselamatan dan kestabilan politik pemerintahan kolonial.

f. Membina suatu perpustakaan historigrafi yang dijadikan sebagai hak milik pribumi yang kemudiannya digunakan sebagai bahan utama pengajaran kepada masyarakat. ${ }^{38}$

Koleksi historiografi milik masyarakat Melayu yang antaranya ada yang berupa manuskrip Melayu-Islam dalam kalangan akademik Barat dianggap sebagai warisan yang sangat berharga. Sejak sekian lama bahan telah dijadikan sumber normatif ataupun bahan kajian utama untuk memahami dan memperihalkan tentang watak manusia Melayu-Islam. ${ }^{39}$ Ironisnya, pendedahan tentang watak dan pencapaian intelektual manusia Melayu-Islam yang difahami oleh sarjana Barat melalui bahan kajian ini seringkali agak mengecewakan. Hal ini berlaku antara lainnya berpunca daripada kelemahan metodologi kajian manuskrip yang dipakai oleh genre orientalisme Barat. ${ }^{40}$

Dalam menghurai watak manusia Melayu melalui koleksi historiografi ini, mereka sejak awal lagi (seperti pre-conveived idea) menetapkan beberapa ciri utama yang kemudiannya diolah dengan pelbagai teknik:

1. Ianya statik dan ahistorical. Orang Melayu sebagai statik dan tidak boleh berubah. Pemikiran ahistorical enggan mengendahkan perubahan yang boleh berlaku dalam persekitaran dan budaya sesuatu masyarakat dari zaman ke zaman. Ia dianggap sebagai sifat semulajadi orang Melayu yang statik dan tidak berubah ke arah kebaikan.

2. Mutunya rendah, mudah, primitif dan irrasional, tetapi bersifat eksotik dan memukau.

3. Bersifat sterotaip dalam bentuk prejudis ras yang ketara. Watak orang Melayu disifatkan malas, fatalis, berpuashati dengan apa yang dimiliki dan berlaku kerana faktor genetik yang rendah.

4. Huraian dalam bentuk reduksionis yang merendahkan orang Melayu, tanpa dikaji apakah sebab kemunduran berlaku kepada orang Melayu.

5. Keasyikan kajian mereka lebih ditumpukan kepada kajian tekstual (filologikal). Ia merupakan usaha mengedit teks yang ditransliterasi dan pencarian kepada versi-versi teks yang asli. Mereka lebih asyik menghurai leksikon dan perubahan semantik yang terdapat dalam teks. Bagi mereka, dengan mengkaji teks, hanya dengan analisis perkataan dan lapisan etimologinya mereka akan menemukan rahsia bagaimana orang Melayu berfikir dan bertindak. Ianya dibuat tanpa mempedulikan kondisi sejarah dan suasana masyarakat yang berkaitan.

6. Mengabaikan penggunaan pendekatan sains sosial diagnostik. Bagi mereka, pendekatan sains sosial agak janggal untuk digunakan mengkaji fenomena sosial orang Melayu.

7. Elemen keunggulan pencapaian manusia Melayu akan dilenyapkan. Sebaliknya hal pencapaian ini dikaitkan dengan usaha gigih kolonialis menjajah dan mentamadunkan orang Melayu.

Hal ini ternyata amat salah sekali kerana kajian tentang objek kemanusiaan perlu menggunakan beberapa paradigma utama; mekanisme, organisme dan kontekstual. Hal ini bersesuaian dengan tren perubahan paradigma keilmuan yang secara lantang disuarakan oleh banyak pihak. Ianya terdiri dari pendekatan:

1. Mekanisme: pendekatan yang lebih terbuka berbanding pendekatan legal formalistik (formism), yang memberikan penekanan kepada sifat pokok sesuatu mekanisme iaitu soal kontinuiti dan mekanis. Menurut paradigma ini semua gejala kehidupan adalah bersifat berkesinambungan dalam proses mekanis yang terus bergerak. Ianya paling disesuai diterapkan dalam kerangka kajian yang membabitkan elemen kemasyarakatan, memandangkan masyarakat manusia bukannya statik dan selalu berubah, samada ke arah yang lebih baik ataupun sebaliknya. 
2. Organisme: seluruh realiti kehidupan pada dasarnya berjalan secara harmonis, berintegrasi, penuh perkaitan antara faktor dalaman dan luaran serta penuh dengan kepastian. Atas dasar ini, kaedah terbaik untuk memahami realiti kehidupan manusia perlu menggabungkan kesemua bentuk disiplin keilmuan, seperti sejarah, sosiologi, ekonomi dan sebagainya. Oleh itu, sebarang usaha untuk menilai manuskrip Melayu perlu dilihat kepada pelbagai aspek kehidupan seperti aspek budaya, sosiologi, agama, politik dan ekonomi sekaligus.

3. Kontekstual: semua fenomena kemanusiaan yang dikaji adalah bersifat kontekstual, tidak ada satupun dalam kehidupan ini yang tidak berkait dengan konteks dan kondisinya yang bersifat khusus. Atas dasar ini, kajian terhadap elemen manusia akan menjadi lebih mendalam sekiranya dilihat kepada aspek kontekstual sesuatu objek yang dikaji. Hasilnya, kita bakal mengetahui bahawa latar belakang masyarakat Melayu silam itu wujud adalah bersifat khusus yang hanya sesuai dengan realiti masyarakat tradisi berbanding dengan kawasan lain. ${ }^{41}$

Selepas merdeka, pendekatan stereotaip ras yang menetapkan pelbagai sifat negatif kepada semua lapisan kaum di Malaysia terus kekal dan disebarkan ke peringkat antarabangsa. Bangsa Melayu dikatakan sebagai bangsa yang malas, suka berkhayal dan tidak boleh dipercayai, bangsa Cina dinisbahkan sebagai bangsa pencandu dan suka berjudi dan bangsa India pula dinisbahkan sebagai bangsa yang lemah daya intelektual, pengotor dan kuat minum todi. Pendedahan yang bersifat stereotaip ini akan menyebabkan semua bangsa Malaysia akan merasa malu dan hilang maruah diri untuk berhadapan dengan bangsa lain di dunia ini. Apa yang lebih buruk lagi, masyarakat Malaysia selepas merdeka akan beranggapan bahawa semua warisan silam bangsa mereka bersifat rendah dan ketinggalan zaman berbanding dengan warisan yang ditinggalkan oleh warisan tamadun Barat, yang juga dikenali sebagai pendekatan euro-centric. ${ }^{42}$

Menurut Syed Farid Al-Attas, kajian tentang semua perkara membabitkan masyarakat jajahan dibuat mengikut paradigma dan kerangka epistemologi ilmu sains sosial Barat (positivisme sekular). ${ }^{43} \mathrm{Jadi}$, para kolonialis menetapkan bagaimana sesuatu masalah masyarakat tanah jajahan perlu diselesaikan mengikut kerangka epistemologi Barat ini. Ia menjadi masalah terbesar yang dihadapi tanpa disedari oleh masyarakat tanah jajahan. ${ }^{44}$ Untuk memahami bagaimana epistemologi ilmu sains sosial Barat, kita boleh merujuk kepada beberapa pendekatan utama:

1. Paradigma yang memandang sesuatu masalah atau gejala dalam masyarakat mengikut world-view positivesme Barat. Apa yang penting dan sebaliknya perlu diatur dan dibuat mengikut world-view kolonial. Contohnya, Raffles memandang dan memberikan takrifan konsep Melayu mengikut world-view Barat yang berasaskan konsep nation state Eropah. Lebih penting lagi, ianya dibuat berasaskan kepentingan kuasa penjajah Barat yang cuba memecahbelahkan kawasan Alam Melayu mengikut pembahagian kawasan jajahan takluk British dan Belanda seperti mana termaktub dalam perjanjian Inggeris-Belanda tahun 1824. Begitu juga halnya dengan pendekatan yang menganggap agama sebagai elemen yang tidak saintifik yang perlu diketepikan dalam proses mendapatkan ilmu. Lebih khusus lagi mereka membezakan antara konsep perkara agama dan bukan agama. ${ }^{45}$

2. Bergantung sepenuhnya kepada teori binaan sarjana Barat. Beberapa contoh boleh diberikan untuk menerangkan pendekatan ini;

a. Konsep masyarakat plural diambil terus daripada teori sarjana kolonial Barat.

b. Sukatan subjek Sejarah Tanah Melayu disusun oleh sarjana Barat. ${ }^{46}$

c. Pengajian Islam dikelompokkan sebagai salah satu bidang sains sosial mengikut neraca Barat. 
d. Sejarah nasionalisme dan gerakan Islam di Tanah Melayu perlu bergantung kepada karya William Roff.

e. Tahap period sejarah Alam Melayu ditetapkan oleh Barat. Ianya menetapkan bahawa zaman keagungan Melayu berlaku kerana proses Indianisasi dan dengan datangnya kuasa Barat yang membawa misi mentamadunkan Alam Melayu.

f. Menafikan sumbangan Islam dalam masyarakat Alam Melayu. Dakwah Islam yang berlaku di Alam Melayu didakwa penuh dengan muslihat kebendaan dan menjurus kepada wujudnya penindasan kepada agama lain.

g. $\quad$ Konsep feudal Barat disamakan dengan sistem feudal Melayu.

h. Sumber historiografi masyarakat tanah jajahan yang diulas oleh sarjana-pentadbir British dianggap sebagai bahan yang berautoriti, walaupun ianya dibuat dalam bentuk yang sangat bias dan tidak betul. ${ }^{47}$

3. Teori dan kerangka analisa ilmu kolonial terhadap masalah sosial, agama dan budaya memang dijadikan asas yang ditiru oleh pengkaji peribumi sendiri. Apa yang menarik, banyak daripada teori dan pendekatan yang salah telah dilakukan proses reviewing oleh pengkaji tempatan. Beberapa contoh boleh diberikan;

a. Pengkaji sastera Melayu menjadikan pendekatan R.O.Winstedt yang bersifat formalistik-philologikal sebagai asas kajian mereka. Pendekatan formalistikphilologikal ini memberikan penekanan kajian sastera kepada beberapa perkara utama (i) kepelbagaian versi teks, (ii) pengarang dan asal usulnya, (iii) pentarikhan karya dan (iv) pengaruh luar yang mendasari karya selain melakukan ikhtisar teks.

b. Pengkaji karya ulama Melayu akan meniru pendekatan M.B. Hooker yang memandang rendah sumbangan ulama Melayu silam yang dikatakan hanya sebagai penterjemah karya-karya ulama Timur Tengah yang baik tanpa disertakan dengan daya analisis yang memasukkan pandangan ulama Melayu sendiri. Beliau juga mendakwa bahawa tiada suatu pun karya ilmu Usul al-Fiqh yang mengupas elemen pemikiran hukum Islam yang tersebar di Alam Melayu. Hal ini telah ditolak oleh beberapa sarjana Melayu seperti Ismail Mat yang menegaskan bahawa ulama Melayu silam secara tuntas telah turut mengulas dan melakukan elemen sentesis yang memperkayakan karya Timur Tengah dengan nilai tempatan ('uruf) Melayu. Contohnya, Hukum Kanun Melaka mustahil dapat dihasilkan oleh sarjana Melayu tanpa berasaskan kepada pemahaman ilmu Usul al-Fiqh yang jitu. ${ }^{48}$

c. Pengkaji Melayu menerima pakai secara sewenangnya teori yang dikemukakan oleh sarjana orientalis yang memperkecilkan peranan Islam di dalam masyarakat Melayu. Mereka mendakwa bahawa Islam hanyalah selaput luar daripada diri masyarakat Melayu, sedangkan isi dalamannya masih lagi secara kuat berpegang kepada ajaran Hindu-Buddha. Teori ini secara langsung telah ditolak oleh S.M. Naquid al-Atas yang membuktikan bagaimana proses Islamisasi Alam Melayu telah berjaya menghakis saki baki ajaran pra-Islam di dalam diri masyarakat Melayu yang digantikan dengan unsur rasionalisme yang cukup tinggi. ${ }^{49}$

d. Pendekatan kajian yang merendahkan sumbangan ulama dalam membawa perubahan kepada masyarakat Melayu. Dalam soal ini, Abdul Aziz Mat Ton telah menolak pendapat William Roff yang memandang rendah sumbangan yang diberikan oleh Majalah al-Imam yang diusahakan oleh Kaum Muda ke arah mewujudkan semangat nasionalisme yang terawal di Tanah Melayu. Kajian Abdul Aziz Mat Ton ini telah mengubah persepsi sejarah perjuangan Islam yang dominan di Tanah Melayu yang menegaskan bahawa golongan anak didik penjajah yang terdiri dari pembesar Melayu merupakan tokoh ulung yang memainkan peranan membangkitkan semangat nasionalisme di Tanah Melayu. Sebaliknya, daripada pembentangan fakta dan tafsiran yang menggunakan serangkaian rekod pihak British, beliau telah berjaya menunjukkan 
bagaimana perjuangan awal kaum muda ini yang kemudiannya diikuti dengan kebangkitan golongan ulama Melayu telah menimbulkan pelbagai masalah kepada pihak British, yang menyebabkan pihak British menguatkuasakan pelbagai bentuk penindasan ke atas ulama Islam. ${ }^{50}$

Di zaman selepas merdeka, ilmu kolonial ini telah dipastikan akan tetap digunapakai oleh masyarakat tanah jajahan. Warisan ini berjaya dilakukan memandangkan hanya golongan elit penjajah (raja dan pembesar Melayu) yang dirangka menjadi pengganti penjajah sebagai pemimpin negara. ${ }^{51} \mathrm{Hal}$ ini memang terbukti benar apabila pewaris ini tetap meneruskan polisi penjajah dalam beberapa dasar. ${ }^{52}$ Antaranya boleh dilihat kepada bentuk Perlembagaan Negara, pemakaian buku teks di sekolah dan universiti mengikut perspektif British, ${ }^{53}$ sistem pemerintahan negara mengikut gaya Westmister, pentadbiran awam dan pentabiran undang-undang bernegara. Lebih parah lagi, ilmu kolonial ini disebarkan kepada pihak IPT Eropah dan badan antarabangsa sebagai bahan ilmiah yang paling berautoriti. Ia merupakan pelbagai kajian yang membabitkan latar belakang manusia Alam Melayu dalam bentuk laporan, hasil bancian, jurnal ilmiah, catatan peribadi, bibliografi dan manuskrip.

\section{Kesalahan Teori Orientalis Barat tentang Sejarah Alam Melayu Peranan Aceh dalam Aktiviti Keganasan di Alam Melayu}

Pemerintah Aceh dengan nasihat ulama digambarkan kerajaan yang ganas dan suka menumpahkan darah orang Barat yang berbeza agama. ${ }^{54}$ Digambarkan oleh pencatat Portugis bagaimana pemerintah Aceh enggan berhubungan dengan baik apabila berhadapan dengan rombongan dagang Portugis. Dalam paparan yang dikemukakan oleh catatan sejarah Portugis terdapat fakta bahawa pihak Portugis beberapa kali cuba mengelakkan peperangan secara baik, kerana matlamat mereka adalah untuk menjalankan perdagangan dengan kerajaan lain di Alam Melayu. Mereka juga menggambarkan secara berlebihan kehebatan tentera Portugis berbanding dengan tentera Aceh. Kerajaan Aceh dicatatkan berusaha memonopoli sumber rempah di Alam Melayu dengan menyerang dan memusnahkan ladang lada hitam di kawasan lain. Aceh juga dikatakan suka menyerang kawasan lain untuk memperluaskan kuasa dan diikuti dengan dasar membawa balik tawanan perang ke Aceh untuk dijadikan hamba dan gundik. ${ }^{55}$ Para hamba ini memang dizalimi oleh masyarakat Aceh. Dalam masyarakat Aceh dikatakan mempunyai ramai hamba dan gundik untuk kepentingan pembesar Aceh. ${ }^{56}$ Sarjana Barat juga melalui catatan pengembara asing telah menggambarkan Aceh mengamalkan sistem undang-undang hudud yang sangat zalim dan tidak berperikemanusiaan. ${ }^{57}$

Dakyah buruk yang dikaitkan dengan kerajaan Aceh ini jika dilihat dari perspektif sejarah Alam Melayu ternyata tidak benar sama sekali. Ini kerana penentangan Aceh adalah untuk menghalang perkembangan agama Kristian yang memang menjadi agenda utama penjajah Portugis. Andainya Aceh tidak mengambil langkah proaktif ini, besar kemungkinan masyarakat Alam Melayu akan menganggap perkembangan agama Kristian sebagai perkara biasa. Lebih penting lagi penjajah Portugis tercatat dalam sejarah sebagai bangsa yang suka menggunakan kaedah kekerasan terhadap masyarakat Islam. Selain itu, mereka juga kerap kali menggunakan kaedah tipu muslihat dalam penyebaran agama Kristian. Hasil usaha Aceh ini memang terbukti berjaya menghalang perkembangan agama Kristian dan mengekalkan dominasi Islam di Alam Melayu. ${ }^{58}$ Dalam paparan sarjana-mubaligh Kristian sendiri, mereka mengakui bahawa Tanah Melayu dan Aceh dianggap kawasan gelap untuk agama Kristian. ${ }^{59}$

Strategik Politik Membesan yang diamalkan oleh kerajaan Aceh penuh hikmah dan dalam bentuk kekeluargaan berasaskan semangat ukhuwah Islam. Apa yang dilakukan melalui taktik ini adalah Aceh berusaha mengahwini raja dan keturunan raja daripada Pahang, Johor, Kedah dan Perak; sebagai kaedah untuk merapatkan hubungan atas dasar ukhuwah Islam dengan keluarga diraja negeri-negeri Melayu. Bukan sekadar hubungan 
ukhuwah Islam, taktik ini juga bakal meraih simpati dan sokongan daripada masyarakat awam yang memang bergantung kepada keluarga diraja yang terbabit.

Dakwan tawanan ditindas adalah tidak betul kerana ramai daripada tawanan perang ini diterima menjadi warga terpenting di Aceh, contohnya Raja Iskandar Thani, Puteri Kamelia dan Tun Seri Lanang. Raja Iskandar Thani asalnya adalah anak raja Pahang yang ditawan yang kemudiannya dilantik menjadi pengganti Raja Iskandar Muda. Begitu juga halnya dengan Puteri Kamelia tawanan daripada Pahang telah menjadi isteri Raja Iskandar muda yang sah. Beliau kemudiannya bertanggungjawab menjadi penasihat di istana membentuk badan mesyuarat negara bagi mendengar masalah masyarakat awam. Kepentingannya terbukti dalam Hadis Maja yang dipakai di Aceh, suatu formula tentang bagaimana pemerintahan negara perlu dilakukan. Masyarakat Aceh menjadi masyarakat kosmopolitan dan hingga sekarang kesannya masih kekal.

Usaha Aceh memerangi kuasa penjajah Portugis dan merapatkan hubungan dengan negeri Melayu telah berjaya mewujudkan ikatan persaudaraan Melayu Islam (the Allied Malay Nationalism) berasaskan hubungan antara kerajaan Aceh, Minangkabau dan Melayu. Usaha Aceh ini dianggap seperti pagar yang menjaga kawasan ummah Islam daripada pencerobohan kuasa kafir. Hal ini turut didokong dengan penggunaan bahasa Melayu sebagai lingua franca di antara kerajaan Melayu dan lebih penting lagi ianya menjadi alat terpenting bagi perkembangan keilmuaan dan intelektual Islam pada abad ke-17. ${ }^{60}$

Aceh mempunyai hubungan yang kuat dengan kerajaan Uthmaniyyah, menjadi pembantu melawan kuasa penjajah dan bertindak sebagai penaung kepada kapal yang membawa jemaah haji Alam Melayu. ${ }^{61}$ Hasilnya, seperti mana dijelaskan dalam catatan Abdullah Munsyi, keadaan kapal jemaah haji Alam Melayu yang dahulunya penuh dengan kesulitan telah menjadi semakin baik dan terjamin. Dasar hubungan Aceh-Othmaniyyah ini menyebabkan semakin kukuh wujudnya masyarakat Jawi di Haramayn (ulama dan pelajar Melayu yang mendalami dan menyebarkan ajaran Islam). Masyarakat Jawi ini kemudiannya menyumbang kepada wujudnya jalinan intelektual antara Alam Melayu dengan Haramyn. Ia secara langsung telah mempercepatkan pemerkasaan world-view dan keilmuan Islam di Alam Melayu dalam bentuk yang tidak pernah terjadi sebelum ini.

\section{Memperlekehkan sumbangan Islam dalam Proses Islamisasi Alam Melayu}

Dalam soal ini, sarjana-pentadbir kolonial mendokong teori Islamisasi daripada India bagi memperlihatkan bentuk ajaran Islam yang sampai ke Alam Melayu dalam bentuk yang tidak murni. Bagi mereka, Islam yang datang ke Alam Melayu ini pada peringkat awalnya bukanlah dalam bentuknya yang sejati tetapi telah dicirikan dengan beberapa aspek negatif melibatkan para mubaligh yang awal. ${ }^{62} \mathrm{Hal}$ ini dapat dilihat dalam beberapa keadaan:

1. Citra Islam yang terpengaruh dengan tamadun era taqlid di dalam dunia intelektual Islam. $^{63}$

2. Islam dalam bentuk kesufian yang kurang menitikberatkan persoalan rasionalisme. ${ }^{64}$

3. Citra Islam yang penuh dengan ciri-ciri popular Islam yang dibawa oleh mubaligh awal. ${ }^{65}$

4. Citra Islam yang terpengaruh dengan ciri-ciri feudalism Timur Tengah dan India. ${ }^{66}$

Mereka secara berlebihan mendakwa Islam tidak memberi apa-apa kesan positif kepada masyarakat Melayu, berbanding dengan proses Indianisasi Alam Melayu sebelumnya. Bahkan pengaruh Indianisasi dilihat lebih positif di dalam membawa elemen tamadun kepada masyarakat Alam Melayu. Hal ini dinilai daripada segi wujudnya artifak hebat, wujud masyarakat yang damai dan tidak memusuhi kuasa Barat. ${ }^{67}$ Lebih penting lagi, mereka berlebihan mengagungkan tamadun kebendaan dan sastera Hindu kepada masyarakat Alam Melayu, walaupun kesemuannya tidak mengandungi penggunaan daya artikulasi kritikal dalam kehidupan bermasyarakat. 
Sarjana kolonial sering menegaskan bahawa proses Islamisasi Alam Melayu yang diusahakan oleh mubaligh yang awal penuh dengan paksaan dan tipu muslihat, serta mengajar masyarakat Alam Melayu untuk bersikap ganas pada golongan bangsa Eropah sebagai akibat daripada semangat Perang Salib yang berlaku di Timur Tengah. Mereka menilai undang-undang Islam yang diamalkan dalam masyarakat Melayu sebagai ketinggalan zaman dan hanya sesuai dipakai dalam konteks masyarakat Timur Tengah abad pertengahan. ${ }^{68}$ Walaupun mereka berusaha mengumpulkan karya manuskrip Melayu Islam yang dianggap sebagai bahan historiografi milik masyarakat Melayu, tetapi ianya dianggap tidak mempunyai apa-apa kepentingan. Lebih buruk lagi, dalam kajian filologi terhadap manuskrip Melayu-Islam ini, mereka secara langsung merendahkan keupayaan sarjana Melayu-Islam. Kewujudan karya-karya ini sepatutnya dijadikan sebagai neraca utama untuk mengetahui tahap kesarjanaan ulama Melayu di dalam usaha mereka mengajar, menyusun dan menerapkan ajaran Islam ke dalam masyarakat. Namun begitu, mereka memandang negatif terhadap pencapaian ulama Melayu yang dikatakan sebagai jumud, ${ }^{69}$ tidak menyumbangkan apa-apa sumbangan yang bermakna dalam keilmuan Islam, ${ }^{70}$ terlalu terpengaruh dengan pendekatan taqlid ${ }^{71}$ dan terlalu mengikut kehendak raja Melayu. ${ }^{72}$

\section{Sikap Skeptikal Terhadap Peranan Sejarah Islam di Alam Melayu}

Sarjana orientalisme secara jelas menafikan autoriti sumber sejarah tempatan Alam Melayu yang dikatakan penuh elemen feudalism dan mitos. Bagi mereka, sumber sejarah Alam Melayu merangkumi Hikayat Raja Pasai, Sejarah Melayu, Hikayat Aceh, Hikayat Siak, Tuhfat al-Nafs dan sebagainya tidak mengandungi apa-apa faedah yang menggambarkan latar belakang sosio-politik-ekonomi dan intelektual masyarakat Alam Melayu. Hal ini telah diulas dengan cukup baik oleh Dr. Tantiana A. Denisova dan Hussain Othman yang mendedahkan mutu intelektual yang terkandung di dalam kesemua sumber sejarah Alam Melayu ini. ${ }^{73}$

Dirujuk kepada elemen epistemologi-metodologinya, genre orientalisme telah melakukan beberapa kesilapan utama dalam menilai sumber sejarah Islam tempatan, termasuklah kepada sumber ajaran Islam itu sendiri. Pertama, mereka melakukan pemaksaan pemakaian konsep sejarah Barat di dalam menilai sumber sejarah Alam Melayu. Antara keduanya, ternyata sekali world-view pegangannya tidak sesuai dengan kontekstual Alam Melayu. Bagi mereka, berasaskan falsafah rasism euro-centric, hanya kerangka epistemologi konsep sejarah mengikut pemahaman Barat sahaja yang dianggap paling betul secara mutlaknya.

Kedua, sebelum kedatangan kuasa kolonial, masyarakat Alam Melayu dianggap tidak memiliki sejarah yang jelas, kabur dan bersifat tradisional. Andainya dilakukan kajian mendalam, ia menunjukkan beberapa perkara:

1. Unsur tradisional dianggap sebagai buruk dan out of date berbanding dengan era moden yang diwakili dengan kedatangan mereka di Alam Melayu.

2. Sebelum mereka datang, orang Melayu tidak bertamadun seterusnya mengajar orang Melayu jangan mempercayai sejarah keunggulan silam. Sebaliknya ia harus dilupakan dan cukup bergantung pada British untuk membawa kemajuan.

3. Kedatangan mereka adalah untuk menyelamatkan orang Melayu daripada kejahatan sendiri. Mereka ingin menunjukkan bahawa kedatangan mereka membawa maksud yang murni dan menyembunyikan niat jahat mereka ingin menjajah dan mengaut hasil bumi masyarakat Melayu. Oleh itu, mereka mencipta teori kejahatan sistem feudal Melayu yang menindas ahli masyarakat. Justeru, bagi menutup kejahatan sendiri mereka menuduh masyarakat Melayu yang jahat.

4. Kononnya hanya sumber catatan mereka sahaja yang bermutu objektif dan boleh dipercayai kerana sumber sejarah tempatan penuh dengan elemen mitos. Sedangkan catatan sejarah mereka penuh dengan kelemahan merangkumi; a) tidak mendalam dan 
dibuat secara sepintas lalu; b) sarat dengan agenda British yang hanya terhad tentang Negeri Melayu Bersekutu dalam temanya hanya berkisar soal kezaliman raja Melayu.

5. Dalam usaha menerangkan kejahatan pembesar Melayu menindas masyarakat sendiri, mereka menggunakan teori Barat (Marx-Kapitalis) untuk menerangkan keburukan sistem feudal Melayu. Masalahnya mana mugkin pengalaman masyarakat luar (Eropah) yang berbeza latarbelakang sejarah kontekstualnya disamakan dengan realiti Alam Melayu.

Mereka membahagikan sejarah kepada dua jenis, sejarah tradisional dan moden. Kononnya, hanya selepas kuasa Barat datang barulah elemen sejarah moden itu timbul yang dianggap sebagai sejarah yang bermanfaat untuk dikaji. Maklumat tempatan tidak diakui kerana penuh dengan elemen mitos, sebaliknya masyarakat Alam Melayu hanya patut bergantung kepada catatan orang Barat tentang masyarakat Melayu untuk mengetahui makna sejarah sebenar. Atas dasar ini, mereka mengisytiharkan sejarah negeri-negeri Melayu seperti Kelantan, Terengganu dan Pahang sebagai kabur dan tidak jelas. ${ }^{74}$ Lebih tepat lagi, mereka enggan mengakui sejarah tamadun Melayu Islam sebelum kedatangan kuasa kolonial. Akibatnya, sejarah tamadun Melayu tradisional dianggap tidak wujud, bahkan ditenggelamkan sama sekali. Sebagai alternatifnya, andainya masyarakat Melayu ingin mengetahui sejarah mereka sendiri, mereka perlu merujuk kepada catatan sarjana kolonial. ${ }^{75}$

Catatan sejarah milik sarjana kolonial ini agak sempit yang hanya tertumpu di Negerinegeri Melayu Bersekutu. Contohnya, sejarah negeri Melayu lain seperti Pahang dikatakan hanya bermula pada abad ke-19. Ia hanya menumpukan kepada isu pergolakan politik yang penuh dengan keadaan huru hara yang memerlukan campurtangan British untuk melahirkan Law and Order di negeri terbabit. Hal ini diterangkan dalam catatan sarjana-pentadbir kolonial dan tali barutnya, Abdullah Munsyi. ${ }^{76}$ Lebih malang lagi, dalam kesemua catatan sejarah ini, masyarakat Melayu digambarkan sebagai masyarakat yang penuh elemen negatif dan penuh penindasan yang dilakukan oleh pembesar kepada masyarakat Melayu. ${ }^{77}$

Daripada kajian yang dilakukan oleh Husin Othman, terdapat sejumlah besar sarjanapentadbir kolonial Portugis, Belanda dan British yang berusaha melakukan kajian tentang masyarakat Melayu. Dalam kesemua karya ini, tren utama yang dipakai adalah cuba memperlihatkan seolah-olah mereka yang menemui dan bertanggungjawab mentamadunkan Alam Melayu. ${ }^{78}$ Karya-karya sarjana-pentadbir kolonial ini walaupun berguna untuk dikaji, tetapi kesemuanya perlu dipandang secara kritikal kerana ianya mempergunakan beberapa paradigma kolonial yang sarat dengan kepentingan kolonial. Antaranya:

Pertama, paradigma yang mendokong kepentingan kolonialism di Alam Melayu. Mereka telah mengkaji hal ehwal Islam dan kebudayaan masyarakat Timur (oriental) dalam semua aspek, khususnya sifat positif dan negatif yang boleh didapati dalam masyarakat sama ada dengan tujuan ilmiah semata-mata atau untuk tujuan keagamaan dan politik. Kajian ini secara langsung bertujuan untuk menjadi alat kepada kuasa politik penjajah, ${ }^{79}$ yang menghuraikan secara terperinci tentang kekuatan dan kelemahan masyarakat timur, yang bakal dipelajari oleh kuasa penjajah demi untuk menguatkan penguasaan mereka terhadap masyarakat tanah jajahan. ${ }^{80}$

Sifat utama kajian-kajian ini mendedahkan dan menyebarkan propaganda kononnya masyarakat Melayu adalah bersifat negatif seperti malas, ${ }^{81}$ suka berfoya-foya, ${ }^{82}$ keras kepala, ${ }^{83}$ tidak boleh diharap, ${ }^{84}$ suka berhutang ${ }^{85}$ dan sebagainya. Demi untuk memperbaiki keburukan ini, kuasa British telah dianggap sebagai penyelamat (saviour) masyarakat Melayu $^{86}$ yang memperkenalkan sistem pendidikan Barat yang berorientasikan materialisme dan pemupukan budaya British yang dianggap baik, yang sayangnya hanya dikhususkan hanya kepada kelas feudal Melayu. ${ }^{87}$ Berasaskan maklumat yang diperolehi oleh kuasa British daripada kajian pakar-pakar pentadbir British yang mendalami budaya Melayu, ${ }^{88}$ mereka telah memperkukuhkan lagi kedudukan kelas feudal Melayu yang dilatih untuk 
menjadi golongan yang berwajah Melayu, tetapi roh dalamannya bersifat British yang dianggap dapat dijadikan sebagai jalan perantaraan yang terbaik untuk menguasai masyarakat Melayu yang secara tradisinya begitu menghormati golongan feudal ini. ${ }^{89}$

Kedua, falsafah evolutionism yang menganggap tamadun Barat sebagai lebih tinggi dan agung, berbanding dengan keadaan masyarakat Timur. ${ }^{90}$ Pencapaian tamadun Barat yang membanggakan ini kononnya disebabkan kerana penerimaan fahaman sekularisme yang menolak kepentingan agama di dalam hidup manusia. ${ }^{91}$ Sebaliknya, masyarakat selain Barat yang masih berpegang kepada agama telah dianggap sebagai mundur, bodoh, bebal dan tidak bertamadun yang harus ditamadunkan oleh masyarakat Eropah, melalui proses penjajahan. ${ }^{92}$ Bahkan kononnya tugas menjajah demi untuk mengajar masyarakat Timur ini telah dianggap sebagai tanggungjawab sosial yang terpaksa dimainkan oleh masyarakat Eropah. ${ }^{93}$

Berdasarkan kepada hal ini, ianya dapat mendorong kebanyakan sarjana Barat yang mengkaji tentang undang-undang adat Melayu memburuk-burukkan undang-undang Islam yang dianggap sebagai ketinggalan zaman, zalim, tidak berperikemanusiaan ${ }^{94}$ dan banyak lagi bentuk keburukan yang dinisbahkan kepada syariah Islam. ${ }^{95}$ Begitu juga semua sifat buruk yang dipunyai oleh orang Melayu dikatakan berpunca dari pengamalan mereka terhadap ajaran Islam, seperti suka berserah kepada takdir, tidak menghargai masa, ${ }^{96}$ menolak pemodenan ${ }^{97}$ dan sebagainya yang perlu diubah dengan memperkenalkan cara hidup Barat, termasuklah sistem undang-undang Eropah. ${ }^{98}$

Ketiga, pendekatan diffusionisme yang menganggap kemajuan masyarakat Melayu bukan kerana sifat asal diri mereka yang baik dan proaktif terhadap sesuatu kemajuan, ${ }^{99}$ tetapi kerana faktor pengaruh budaya asing (difusi budaya) yang secara langsung telah ditiru oleh masyarakat Melayu. ${ }^{100}$ Sikap ini secara terang telah menafikan kepandaian masyarakat tempatan (local genius) di dalam membina sesebuah tamadun tempatan. ${ }^{101}$ Antara budaya asing yang kononnya telah mencirikan kebudayaan Melayu adalah Hindu-Budhha, Arab, India dan Parsi. Bahkan apabila mengkaji pengaruh Islam terhadap jati diri orang Melayu, mereka telah menggambarkannya secara skeptik dengan mengatakan bahawa masyarakat Melayu sebenarnya tidak mempunyai pegangan keislaman yang cukup kuat, hanya di lapisan kulit luar semata-mata, sedangkan isi dalamnya masih lagi berteraskan budaya pra-Islam (animisme dan Hindu). ${ }^{102}$ Secara keseluruhannya, ianya dapat mengesan bagaimana kajian mereka terhadap kebudayaan Melayu kebanyakannya berteraskan sifat anti Islam yang terbawa-bawa dari semangat Perang Salib ${ }^{103}$ dan kebencian mereka terhadap pengalaman penentangan yang telah dicetuskan oleh masyarakat Islam di tanah jajahan yang berada di bawah penguasaan kuasa Barat. ${ }^{104}$

Daripada huraian di atas, kita dapat mengatakan bahawa sejarah masyarakat Melayu mengikut paparan kuasa kolonial memang dizalimi, sehingga dinafikan sejarah pencapaian gemilang yang dibawa oleh program Islamisasi. Kajian mereka bukannya bermutu seperti didakwa kerana beberapa sebab utama iaitu penuh dengan bias dan agenda Barat, bukannya mendalam dan hanya pandangan sepintas lalu semata-mata dan huraian dibuat menggunakan paradigma dan falsafah Barat.

Di zaman selepas merdeka, ilmu kolonial telah mula dikritik hebat oleh sarjana tempatan. Berbanding dengan pendekatan keilmuaan era penjajah, kita dapat mengesan usaha sarjana tempatan melakukan rekonstruksi sejarah tempatan dari perspektif yang lebih holistik. Ianya membabitkan skop yang agak luas merangkumi bidang perundangan Islam, perundangan, sastera, sains sosial, pentadbiran awam, ekonomi, pendidikan, pemikiran, pengurusan dan sebagainya. ${ }^{105}$

\section{Kesimpulan}

Sebagai rumusan akhir, kita dapat mengatakan bahawa penjajahan kuasa Barat di Alam Melayu antara lainnya telah melahirkan ilmu kolonial yang digunakan untuk mengkaji 
masyarakat tanah jajahan secara lebih tuntas. Walaupun diakui asas epistemologi-metodologi ilmu kolonial ini bias kepada kepentingan Barat, tetapi ia telah berjaya mengkonstruk dan mempengaruhi serba serbi kehidupan masyarakat tanah jajahan yang tetap kekal dipegang walaupun pihak kolonial telahpun meninggalkan Tanah Melayu. Sebagai usaha mendaulatkan sejarah masyarakat Melayu, kesemua ilmu kolonial ini berserta dengan dasar yang timbul daripadanya perlu dikaji secara kritikal bagi memperbetulkan semua kesalahan yang terkandung di dalamnya.

\section{Nota}

${ }^{1}$ Paparan tentang bangsa Eropah yang merantau ke Alam Melayu sejak zaman awal boleh dilihat dalam Raja Masittah Raja Ariffin, "Konsep Merantau Ke Alam Melayu: Serampang Banyak Mata", International Journal of The Malay World and Civilization, v. 1 (2), 2013, hlm. 115-125.

${ }^{2}$ Mereka terdiri daripada pedagang British di Abad ke-18 seperti Alexander Hamilton, Thomas Forrest, Francis Light dan Kapten Joseph Jackson yang pernah ke Kuala Terengganu. Lihat Sivachandralingam Sundara Raja "Sumbangan Pedagang Negeri (Country Traders) Dalam Penulisan Sejarah Malaysia”, dalam Mohamed Redzuan Othman (ed.), Jendela Masa: Kumpulan Esei Sempena Persaraan Dato' Khoo Kay Kim, Kuala Lumpur: Penerbit UM, 2001, hlm. 85-88.

${ }^{3}$ Istilah core dimaksudkan sebagai "kawasan yang menjadi tempat perdagangan, membekal keperluan yang sesuai kepada pelaut, membekal makanan, air dan tempat menginap serta gudang simpanan barangan dan pasar." Ahmad Jelani Hakim, Perdagangan dan Pekapalan Melayu Di Selat Melaka, hlm. 4.

${ }^{4}$ Sivachandralingam Sundara Raja, "Sumbangan Pedagang Negeri (Country Traders) Dalam Penulisan Sejarah Malaysia”, hlm. 86.

${ }^{5}$ Carolina Lopez, "The British Presence in The Malay World: A Meeting of Civilization Traditions", SARI, 19, 2001, hlm. 3-33.

${ }^{6}$ Abdul Rahman Embong, Negara-Bangsa: Proses dan Perbahasan, Bangi, 2000, hlm. 34-43.

${ }^{7}$ Muhammad Abu Bakar, "Dari Pusat Ke Penggiran: Masa Kini dan Masa Depan Pondok Di Malaysia”, Jurnal Pendidikan Islam, v. 3, bil 1, 1990, hlm. 17-18.

${ }^{8}$ Syed Muhd Khairudin Al-Junied, "Western Images of Meccan Pilgrims In The Dutch East Indies, 1800-1900", SARI, 23, 2005, hlm. 105-122.

${ }_{9}$ Mehmet Ozay, "A Revisiting Cultural Transformation: Education System In Malaya During The Colonial Era”, World Journal of Islamic History and Civilization, v. 1 (1), 2011, hlm. 37-48.

${ }^{10}$ Siddiq Fadhil, "Tulisan Jawi: Plestarian dan Pendaulatannya Di Alam Melayu”, Seminar Tulisan Jawi 1995, Kuala Lumpur, 1995, hlm. 6.

${ }^{11}$ Muhammad Abu Bakar, "Dari Pusat Ke Penggiran: Masa Kini Dan Masa Depan Pondok Di Malaysia", hlm. $10-12$.

12 Shamsul Amri Baharuddin, "Perancangan Pembangunan Negara Selepas Merdeka 1957-1975: Tinjauan Sejarah Perkembangan Sosio-Ekonomi Malaysia”, dalam Malaysia: Sejarah dan Proses Pembangunan, Kuala Lumpur, 1983, hlm. 337-339.

${ }^{13}$ Abdul Shukor Ariffin dan Hasan Haji Ali, "Pergolakan Dasar Ekonomi Negara Sebelum dan Selepas 1969", dalam Malaysia: Sejarah dan Proses Pembangunan, Kuala Lumpur, 1983, hlm. 307-308.

${ }^{14}$ R.O. Winstedt, “A History of Perak”, dalam JMBRAS, 12(1), 1934, hlm. 73.

${ }^{15}$ F. Swettenham, About Perak, Singapore, 1893, hlm. 5 dan 9.

${ }^{16}$ Mohd Hazim Shah Abdul Murad, "Epistemology Colonial: Satu Analisistem Ciri dan Kesannya", Dalam Mohamad Daud Mohamad (ed.), Pascakolonialisme Dalam Pemikiran Melayu, Kuala Lumpur: DBP, 2005, hlm. 91-92.

${ }^{17}$ Hadijah Rahmat, In Search Of Modernity: A Study of The Concepts Of Literature, Authorship And Notion Of Self In Traditional Malay Literature, Kuala Lumpur, 2001, hlm. 19-22.

18 Wan Yahya Wan Ahmad, "The Early Development of Islamic Education In Kelantan", ISLAMIKA, Kuala Lumpur, v. 111, 1985, hlm. 221-222.

${ }^{19}$ T.N. Harper, The End Of Empire And The Making of Malaya, Cambridge, 1999, hlm. 18-26.

${ }^{20}$ Terdapat ungkapan buruk yang diberikan oleh pentadbir British tentang sifat terhad sistem pendidikan ala British yang diperkenalkan oleh kuasa British. Lihat Adnan Haji Nawang, Za'ba dan Melayu, Kuala Lumpur, 1998, hlm. 96-97.

${ }^{21}$ Hadijah Rahmat, In Search of Modernity, hlm. 9-12. 
${ }^{22}$ Moshe Yegar, Islam and Islamic Institutions in British Malaya, Jerusalem, 1979, hlm. 187-234.

${ }^{23}$ Syed Hussein al-Attas, The Myth of The Lazy Native, London, 1977, hlm. 42-44.

${ }^{24}$ Chai Hon Chan, The Development of British Malaya, 1896-1909, Kuala Lumpur, 1967, hlm. 276.

${ }^{25}$ Abdul Shukor Ariffin dan Hasan Haji Ali, "Pergolakan Dasar Ekonomi Negara Sebelum dan Selepas 1969", Dalam Malaysia: Sejarah Dan Proses Pembangunan, Kuala Lumpur, 1983, hlm. 307-308.

${ }^{26}$ Adeline M. Koh, Inventing Malayness: Race, Education and Englishness in Colonial Malaya, Tesis Ph.D, University of Michigan, 2008.

${ }^{27}$ Samuel Wee Tien Wang, British Strategic Interests in The Straits of Malacca 1786-1819, Tesis Sarjana, Simon Fraser University, 1991.

${ }^{28}$ Sudibyo, "Kembali Ke Filologi: Filologi Indonesia dan Tradisi Orientalisme", Humaniora, v. 19, 2007, hlm. 107-118.

${ }^{29}$ Boxer, CR, "Some Portuguese Sources For Indonesian Historiography", Dalam Soedjatmoko (ed.), An Introduction To Indonesian Historiography, New Haven: Cornell University Press, 1965.

${ }^{30}$ Ibid.

${ }^{31}$ Barlow, HS, Swettenham, Kuala Lumpur: Southdene Bhd, 1995, hlm. 1-31.

${ }^{32}$ Hussain Othman, "Malay Muslim History as Seen By Western Colonialist", World Journal of Islamic History And Civilization, v.1 (2), 2011, hlm. 117-129.

${ }^{33}$ Kees Groeneboer (1999), "Politik Bahasa Kolonial Di Asia”, Wacana, v. 1, no 2, 1999, hlm. 201-220.

${ }^{34}$ Shamsul Amri Baharuddin (1983), "Perancangan Pembangunan Negara Selepas Merdeka 1957-1975: Tinjauan Sejarah Perkembangan Sosio-Ekonomi Malaysia", hlm. 337-339.

${ }^{35}$ Natalie A. Mault, Java As A Western Construct: An Examnination Of Sir Stamford Raffles's History of Java, Tesis Sarjana, Louisiana State University, 2005.

${ }^{36}$ Ia adalah falsafah ilmu barat yang dipakai dalam bidang sains moden. Ia hanya mengakui kebenaran ilmiah dalam erti positivisme, iaitu apa yang dapat dibuktikan kebenarannya secara empirikal. Jika objeknya bersifat non-empiris- metafizik atau tidak boleh dibuktikan secara empirikal, maka status keilmiahannya diragukan atau bahkan ditolak dan hanya boleh disebut sebagai "psudo atau quasi ilmiah" (menyerupai ilmiah). Mulyadhi Kartanegara, "Membangun Kerangka Ilmu, Perspektif Filosofis", dalam Komaruddin Hidayat dan Hendro Prasetyo (ed.), Problem dan Prospek IAIN, Antologi Pendidikan Islam Tinggi, Depag. RI: Dirjen Bimbaga Islam, 2000, hlm. 252; Mulyadhi Kartanegara, Panorama Filsafat Islam, Bandung: Mizan, 2002, hlm. 59.

${ }^{37}$ Syed Muhd Khairudin Al-Junied, "From Noble Muslims to Saracen Enemies: Thomas Stamford Raffles's Discourse on Islam In The Malay World", SARI, 21, 2003, hlm. 13-29.

${ }^{38}$ Ibid.

${ }^{39}$ Rahimin Affandi Abd. Rahim, "Citra Islam Dalam Pembentukan Manusia Melayu Moden Di Malaysia: Suatu Analisa", Jurnal Pengajian Melayu, v. 15, 2005, hlm. 19-51.

${ }^{40}$ Mohd FarhanAbd Rahman dan Rahimin Affandi Abd Rahim, "Pandangan Orientalis Terhadap Masyarakat Islam Di Tanah Melayu: Analisa Terhadap Karya Pilihan R.O. Winstedt", Jurnal Fiqh, 2012.

${ }^{41}$ Prof Dr Mastuhu, "Penelitian Agama Islam: Perspektif Antar Disiplin Ilmu: Tinjauan Disiplin Sosiologi", Dalam Tradisi Baru Penelitian Agama Islam: Tinjauan Antar-Disiplin Ilmu, Bandung: Penerbit Nuansa, 1998, hlm. 91-104.

${ }^{42}$ Arba'iyah Mohd Noor, "Pensejarahan Di Dalam Tradisi Barat Dan Melayu: Satu Perbandingan Ringkas", Dalam Redzuan Othman(ed.), Jendela Masa, Kuala Lumpur: Penerbit UM, 2001, hlm. 26-27.

${ }^{43}$ Syed Farid Al-Atas, "Orientalisme Dalam Pengkajian Sejarah Alam Melayu”, SOCIA, v. 11, no. 2, 2012, hlm. 245-256.

${ }^{44}$ Syed Farid Al-Atas, "Alternative Discourse in Southeast Asia”, SARI 19, 2001, hlm. 49-67.

${ }^{45}$ Ibid.

${ }^{46}$ Soda Naoki, "The Malay World in Texbooks: The Transmission of Colonial Knowledge in British Malaya", Southeast Asian Studies, v. 39, no. 2, 2001, hlm. 188-230.

${ }^{47}$ Iza Hussin, "The Pursuit of Perak Regalia: Islam, Law And The Politics of Authority in The Colonial State", Law And Social Inquiry, V. 32, Issue 3, 2007, hlm. 759-788.

${ }^{48}$ Rahimin Affandi Abd. Rahim, "Pengamalan Ilmu Usul Al-Fiqh Di Dalam Sastera Undang-Undang Melayu: Satu Analisa", Dalam Muhammad Mokhtar Hassan (ed.) Kesusasteraan Dan Undang-Undang, Penerbitan Akademi Pengajian Melayu, Universiti Malaya, 2003, hlm. 158-179.

${ }^{49}$ S.M. Naquid al-Attas, Preliminary Statement on a General Theory of the Islamization of the MalayIndonesian Archipelago, Kuala Lumpur, 1969.

${ }^{50}$ Lihat Abdul Aziz Mat Tom, Politik al-Imam, Kuala Lumpur: Dewan Bahasa Pustaka, 2000.

${ }^{51}$ Khasnor Johan, "Perkhidmatan Tadbir Melayu: Tradisi Dan Peranan Dalam Konteks Kerajaan Penjajah", dalam Malaysia: Sejarah Dan Proses Pembangunan, Kuala Lumpur: Persatuan Sejarah Malaysia, 1983, hlm. 134-145. 
${ }^{52}$ Shaharuddin Maaruf, Konsep Wira Dalam Masyarakat Melayu, Singapura: Pustaka Antara, 1993, hlm. 99116.

${ }^{53}$ A.J. Stockwell, "The Crucible of The Malayan Nation: The University and The Making of A New Malaya. 1938-1962", Modern Asian Studies, v. 43, 5, 2009, hlm. 1149-1187.

${ }^{54}$ Snouck Hurgronje, Aceh Di Mata Kolonialis, Terjemahan Ng Singarimbun Daripada Buku The Achenese, Jakarta: Yayasan Soko Guru, 1985.

${ }^{55}$ William Gervase Clarence Smith, "Enunuchs and Concubines in The History of Islamic Southeast Asia", Manusya: Journal of Humanities, Special Issue no 14, 2007.

${ }^{56}$ Ingrid Saroda Mitrasing, The Age of Aceh and The Evolution of Kingship 1599-1641, Tesis Ph.D, University of Leiden, 2011, hlm. 232-256.

57 Jajat Burhanudin, "The Dutch Colonial Policy on Islam: Reading The Intellectual Journey of Snouck Hurgronje", Al-Jami'ah: Journal of Islamic Studies, v. 52, no. 1, 2014, hlm. 25-58.

${ }_{58}$ M. Dien Madjid, "Knitting Togetherness Among The Allied Malay: Aceh-Minangkabau-The Malay Peninsula", Tawarikh: International Journal For Historical Studies, v. 4(1), 2012, hlm. 1-17.

${ }^{59}$ Charles Tisdall, "Ideas of Mohammedan Malaya", The Missionary Review of The World, v. xxxiv, 1916, hlm. 348-349.

${ }^{60}$ Amirul Hadi, Islam and State In Sumatera: A Study of Seventeenth Aceh, Leiden: E.J.Brill, 2004.

${ }^{61}$ Ermy Azziaty Rozali, "Aceh-Ottoman Relation In Bustan A-Salatin", Mediterranean Journal of Social Science, v. 5, no. 29, 2014, hlm. 93-99.

${ }^{62}$ Aliza Elias, "Kecenderungan Paksi India: Implikasinya Terhadap Pensejarahan Islam Di Alam Melayu", Mohd Zaidi Ismal (ed.) Adab Dan Peradaban: Karya Pengi'tirafan Untuk Syed Muhammad Naquib Al-Attas, MPH Publishing, 2012, hlm. 609-627.

${ }^{63}$ Abdul Majeed Mackeen, "Contemporary Islamic Legal Organization In Malaya”, Southeast Asian Studies, no. 13, New Haven, 1969, hlm. 14-16.

${ }^{64}$ Idris Zakaria, "Mengapa Melayu Tiada Ahli Falsafah", Pemikir, Oktober-Disember 2000, hlm. 106-114.

${ }^{65}$ Mohd Taib Osman, "Islamization of The Malays: A Transformation Of Culture", dalam Readings on Islam in Southeast Asia, Singapore, 1985, hlm. 44-45.

${ }^{66}$ Rahimin Affandi Abd. Rahim, "Budaya Taqlid", hlm. 35-37.

${ }^{67}$ Mohd Zariat Abdul Rani (2005), "Antara Islam dan Hinduisme Di Alam Melayu: Beberapa Catatan Pengkaji Barat”, SARI, v. 23, 2005, hlm. 67-82.

${ }^{68}$ Mohd Farhan Abd Rahman dan Rahimin Affandi Abd Rahim, "Pandangan Orientalis Terhadap Masyarakat Islam Di Tanah Melayu: Analisa Terhadap Karya Pilihan R.O. Winstedt”, Jurnal Fiqh, 2012.

${ }^{69}$ M.B. Hooker, Islamic Law in Southeast Asia, Singapore, 1984, hlm. 36.

${ }^{70}$ A.H. John, "Islam In The Malay World", dalam Islam In Asia, Jerusalem, v. 2, 1984, hlm. 138.

${ }^{71}$ M.B. Hooker, "The Translation of Islam Into South-East Asia", dalam Islam In South-East Asia, Leiden, 1983, hlm. 9-11.

${ }^{72}$ Patrick Sullivan, Social Relations of Dependence in A Malay State: Nineteenth Century Perak, Kuala Lumpur, 1982, hlm. 76.

${ }^{73}$ Hussain Othman, "Conceptual Understanding of Myths and Legends In Malay History", SARI, v. 26, 2008, hlm. 91-110.

${ }^{74}$ W. A. Graham, Kelantan: A State of The Malay, Glasgow, 1908, hlm. 38; A. Rentse, "History of Kelantan 1", JMBRAS, XII, pt. 2, 1934, hlm. 44.

${ }^{75}$ Hanapi Dolah, "Struktur Dan Hubungan Masyarakat Melayu Tradisional Berdasarkan Sejarah Melayu: Satu Perbincangan Teoritis", SARI, v.1(2), 1983, hlm. 125-139.

${ }^{76}$ Mohammad Saleeh Rahamad, "Pengaruh Barat Dalam Persuratan Awal Di Malaysia", Jurnal Pengajian Media Malaysia, v. 11, no.1, 2009, hlm. 113-132.

${ }^{77}$ Hanapi Dolah, "Struktur Dan Hubungan Masyarakat Melayu Tradisional Berdasarkan Sejarah Melayu: Satu Perbincangan Teoritis", hlm. 125-139.

${ }^{78}$ Hussain Othman, "Malay Muslim History As Seen By Western Colonialist", World Journal of Islamic History And Civilization, v.1 (2), 2011, hlm. 117-129.

${ }^{79}$ Asaf Hussain, "The Ideology of Orientalism", dalam Orientalism, Islam and Islamist, 1984, hlm. 5-22.

${ }^{80}$ Hamid Alqar, "The Problem of Orientalist", Islamic Literature, v. xvii: 2, 1971, hlm. 35.

${ }^{81}$ A. Wright dan T.H. Reid, The Malay Peninsula, London, 1912, hlm. 315.

${ }^{82}$ E. G. De Eredia, "The Description of Malaca", JMBRAS, v. 8:1, 1930, hlm. 31.

${ }^{83}$ T.S. Raffles, Memoir of the Life and Public Services of Sir Stamford Raffles, London, v. 1, 1930, hlm. 91 dan 288-289.

${ }^{84}$ W. L. Richmond, The Modern Malay, London, 1928, hlm. 95 dan 223.

${ }^{85}$ F. Swettenham, Malay sketch, Singapore, 1895, hlm. 2-3. 
${ }^{86}$ Dalam soal ini Winstedt dengan fanatiknya telah menegaskan: "Though his very name has been forgotten at Kuala Kangsar, Captain James Low was the saviour of Perak... and along with the name of Low, Perak ought to enscribe in the letters of gold the name Robert Fullerton, Governor of Prince of Wales Island, Singapore and Malacca”. Lihat R.O. Winstedt, “A History of Perak”, JMBRAS, 12 (1), 1934, hlm. 73.

${ }^{87}$ R. Wheeler, The Modern Malay, Singapore: Oxford University Press, 1996, hlm. 200.

${ }^{88}$ Sebagai contohnya seorang sarjana British dalam menceritakan kepentingan mempelajari budaya Melayu telah menegaskan: "an understanding of the ideas and modes of thought of an alien people in a relatively low stage of civilization facilitates very considerably the task of governing them". Lihat W.W. Skeat, Malay Magic: Being an introduction to the Folklore and Popular Religion in the Malay Peninsula, New York, 1967, hlm. ix.

${ }^{89}$ Khasnor Johan, "Perkhidmatan Tadbir Melayu: Tradisi Dan Peranan Dalam Konteks Kerajaan Penjajah", dalam Malaysia: Sejarah Dan Proses Pembangunan, Kuala Lumpur, 1979, hlm. 134-145.

${ }^{90}$ Edward Said, Covering Islam, How The Media and The Experts Determine Hows We See The Rest of The World, London, 1981, hlm. 39-40, 60 dan 62.

${ }^{91}$ Zainal Kling, “Antropologi Tafsiran: Sumbangan Kebudayaan Melayu kepada Teori”, Syarahan perdana untuk pengukuhan profesor, Kuala Lumpur, 1994, hlm. 12-13.

${ }^{92}$ Sebagai contohnya Frank Swettenham menyatakan bagaimana Raja Muda Abdullah telah meminta kuasa British untuk campurtangan di Negeri Perak dengan tujuan: "to teach him how to rule this unruly country, but the circumstances alone made that interference the duty of the paramount power". Lihat F. Swettenham, About Perak, Singapore, 1893, hlm. 5 dan 9.

${ }^{93}$ Wang Gungwu, Scholarship and the History and Politics of Southeast Asia, Flinders University of South Australia, 1970, hlm. 11.

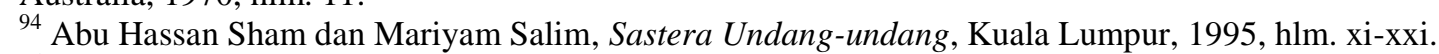

${ }^{95}$ Rahimin Affandi Abdul Rahim (1999), Islamic Legal Reform in the Administration of Islamic Law in Malaysia: A critical analysis, Tesis Ph.D, University of Birmingham, 1999, hlm. 332-334.

${ }^{96}$ F. Swettenham, Malay sketch, hlm. 3.

${ }^{97}$ F. Swettenham, British Malaya, London, 1955, hlm. 136-141.

${ }^{98}$ Rahimin Affandi Abdul Rahim, "Budaya Taqlid Di Dalam Masyarakat Melayu: Suatu Tinjauan Ringkas", Jurnal Syariah, v. 3, bil. 1, 1995, hlm. 37-38.

${ }^{99}$ Zainal Kling, “Antropologi Tafsiran: Sumbangan Kebudayaan Melayu kepada Teori”, hlm. 8-10.

${ }^{100}$ Ibid.

101 Bryan S. Turner, "Gustave E. Von Grunebaum and the Mimesis of Islam", dalam Orientalism, Islam and Islamist, 1964, hlm. 193-202.

102 J.C. Leur, Indonesian Trade and Society, The Hague, 1955, hlm. 169; K.P. Landon, Southeast Asia: Crossroad of religions, Chicago, 1949, hlm. 134-164.

${ }^{103}$ Ahmad Shalaby, Masyarakat Islam, terj. Prof. Mukhtar Yahya, Singapore, 1966, hlm. 349.

${ }^{104}$ Zakaria Stapa, Masyarakat Islam dan Isu Semasa, Kuala Lumpur, 1994, hlm. 56-58.

105 Azmi Aziz, "Transisi Penting Sistem Berkerajaan Di Alam Melayu: Kes Malaysia”, Akademika, 81 (2), 2011, hlm. 79-92. 